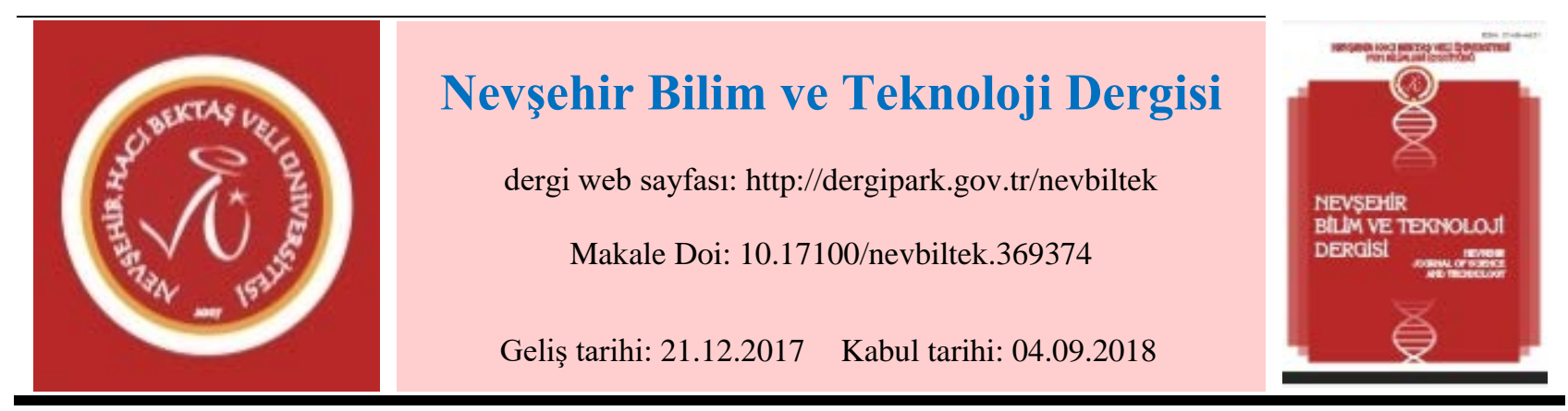

\title{
Matlab / Simulink kullanarak STATCOM ile Güneş Fotovoltaik-Rüzgar Hibrit Enerji Sisteminin Performans Analizi ve Simülasyonu
}

\author{
Hale BAKIR $^{1,}$, Ahmet Afşin KULAKSIZ ${ }^{2}$ \\ ${ }^{1}$ Selçuk üniversitesi, Mühendislik Fakültesi, Elektrik-Elektronik Müh. Bölümü, Konya \\ ORCID ID: https://orcid.org/0000-0001-5580-0505 \\ ${ }^{2}$ Selçuk üniversitesi, Mühendislik Fakültesi, Elektrik-Elektronik Müh. Bölümü, Konya \\ ORCID ID: https://orcid.org/0000-0003-3216-8185
}

Öz

Elektrik talebi arttıkça, güç sistemleri de daha karmaşık hale gelmektedir. Gerilim istikrarsılı̆̆g ve büyüyen karmaşık sistemlerde çökmelerin önlenmesi için kullanılan klasik yöntemler bazen sistemin ihtiyaçlarını karşılamada başarısız olmuştur. Günümüzde, esnek alternatif akım iletim sistemleri (FACTS) ile karmaşık ve büyüyen sistemlerin güç sorunları daha hızlı ve etkili bir şekilde cevap vermektedir. Buna ek olarak, FACTS cihazları uygun bir şekilde kullanıldığında, güç sistemlerinin kararlılık sınırlarını artırmakta ve yük artışı ya da yenilenebilir enerji kaynaklarının sisteme eklenmesi ile oluşan gerilim dalgalanmasını minimize ederek, reaktif güç kompanzasyonu sağlamakta ve mevcut kaynakların mümkün olan en iyi şekilde kullanılmasını sağlamaktadır. En tanınmış FACTS cihazları arasında Static VAR Kompensator (SVC), Static Senkron Kompensator (STATCOM) bulunmaktadır. Bu çalışma MATLAB / SIMULINK'te STATCOM ile Rüzgar-PV Hibrit üretim sisteminin modellenmesi ve analizi üzerine odaklanmaktadır. STATCOM'un hibrit yenilenebilir enerji sistemi (HRES) üzerindeki etkisi araştırılmıştır. STATCOM, iletim sistemlerinde reaktif güç kompanzasyonu sağladığı için, sistem tarafından arzu edilen reaktif güç absorbe edilmekte veya üretilmektedir.

Anahtar Kelimeler: PV modeli, Rüzgâr Modeli, Hibrid Sistem Modeli, STATCOM, FACTS

\section{Performance Analysis and Simulation of Solar PV-Wind Hybrid Energy System with STATCOM using Matlab/Simulink}

\begin{abstract}
As demand for electricity increases, the power systems become more complex. The classic methods used to prevent voltage instability and collapses in growing and complicated systems have sometimes failed to meet the needs of the system. Today, with Flexible Alternating Current Transmission Systems (FACTS), the power problems of complex and growing systems respond more quickly and effectively. In addition, FACTS devices, when used properly, increase the stability limits of power systems and provide reactive power compensation by minimizing the voltage ripple resulting from the increase in load or the addition of renewable energy sources to the system, and ensure that the available resources are used in the best possible manner. Nowadays, among the most well-known FACTS devices are Static VAR Compensator (SVC), Static Synchronous Compensator (STATCOM). This study focuses on the modeling and analysis of Wind-PV Hybrid generation system with STATCOM in MATLAB/SIMULINK. The impact of STATCOM on the hybrid renewable energy system (HRES) has been investigated. As STATCOM provides reactive power compensation in transmission systems, the desired reactive power is absorbed or produced by the system.
\end{abstract}

Keywords: PV model, Wind Model, Hybrid system Model, STATCOM, FACTS

\footnotetext{
${ }^{1} \mathrm{Bu}$ çalışma Nevşehir 2. Materyal Bilimi ve Teknoloji konferansında tam metin bildiri olarak sunulmuştur.

Sorumlu yazar e-mail: haleb@selcuk.edu.tr
} 


\section{Introduction}

In parallel with the world population and industrial developments, the energy requirement is increasing, while the reserves of fossil energy resources are rapidly depleting. Today, despite the use of fossil fuels such as coal, oil, and natural gas in energy production, the rapid depletion of these resources has increased our tendency towards renewable energy sources.

In this respect, projects on renewable energy sources have made great strides in recent years to meet the increasing demand for energy. In recent years, energy has come to the center of researchers and policies. In the global energy balance, fossil fuels such as coal, oil and natural gas maintain their weight in primary energy sources used in the world and our country. The fact that these energy sources are becoming less and less, the tendency towards the sustainable energy resources and the work done on these resources are increasing. A significant advantage of renewable energy sources is that they can form a hybrid system with other energy sources. Hybrid energy systems are generally systems in which two or more different energy production systems work together to supply electricity or thermal load. Hybrid systems that use the wind and solar energy together from renewable energy sources are being investigated extensively [1].

As demand for electricity increases, power systems are becoming more complicated as well. The classic methods used to prevent voltage instability and collapses in growing and complicated systems have sometimes failed to meet the needs of the system. Nowadays, due to FACTS, the power problems of the complicated and growing systems are solved more quickly and effectively. In addition, when FACTS devices are used appropriately, they increase the stability limits of power systems and ensure that the available resources are used in the best possible way [6].The most well-known FACTS devices are Static VAR Compensator (SVC) and Static Synchronous Compensator (STATCOM).

Transmission line switching must be fast and efficient to provide reactive power control, desired voltage levels and system stability to support dynamic disruptive effects such as voltage sags, short circuits, load changes. These characteristics can be obtained using FACTS controllers. Among these devices, thyristor based devices such as TCR (Thyristor controlled reactor), TSC (Thyristor switched capacitor) and TCSVC (Thyristor controlled static var compensator) were used first. Nowadays, controlled switches such as GTO, IGBT, IGCT are applied in base devices. Among these devices, STATCOM (Static Synchronous Compensator) based on a voltage source converter is one of the most used devices [8].

\section{Material and Method}

STATCOM is connected in parallel to the transmission line to extract controlled reactive power from the transmission line and regulate the line voltage. This is the main task of STATCOM. It can supply reactive power to the transmission line or can dissipate reactive power from the transmission line to regulate amplitude of the voltage at the output of the transformer. If the converter output is at the forward phase, it gives active power to the system, while at the reverse phase it draws active power from the system. Generally, STATCOM supplies reactive power to the system. The structure of STATCOM is shown in Figure 1 [5]. 


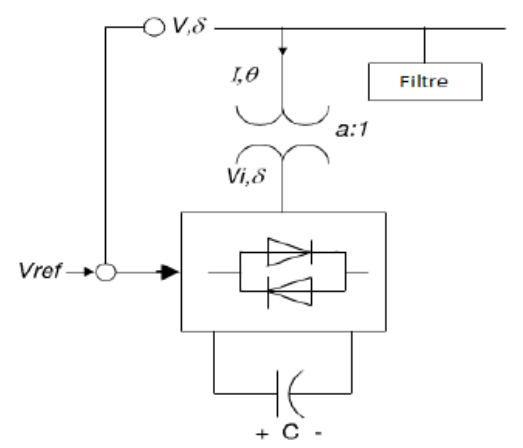

Figure 1. Structure of STATCOM

The main task of this paper is to develop a simulation model of a standalone hybrid generation system including wind and PV subsystems with STATCOM using MATLAB/SIMULINK. Characteristics of modeled wind turbine and PV panel and STATCOM have been shown for different conditions. This paper includes in detail the equations that form the wind turbine and PV panel. Accordingly, necessary information is provided to develop wind turbine models and PV panel and STATCOM that can be used in the simulation for wind/PV generation system and for further study of such systems. The proposed hybrid system model is shown in Figure 2.

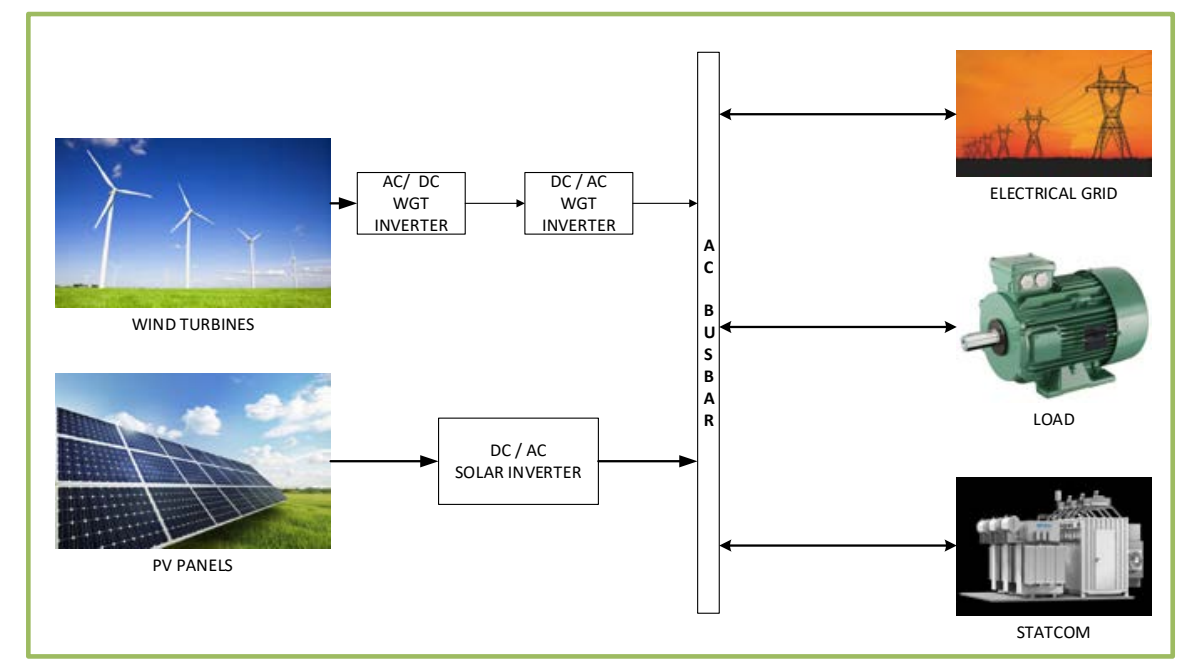

Figure 2. Proposed hybrid system model

\subsection{PV cell modeling}

Solar cells consist of p-n semiconductors being combined into a thin layer. The PV cell output I-V characteristic in the dark is very similar to that of a diode. When exposed to light, due to electron movement driven by photons, current is supplied. PV cell equivalent circuit is shown in Figure 3. The circuit is expressed by a diode connected in parallel to the current source, a shunt resistor $R_{s h}$, and a resistor $R_{s}$ connected in series to resulting structure. 


\section{Nevşehir Bilim ve Teknoloji Dergisi (2018), 7(2) 135-144}

The photon generated current shorting together the terminals of the cell will flow out of the cell as a shortcircuit current $\left(\mathrm{I}_{\mathrm{sc}}\right.$ ). Therefore, $\mathrm{I}_{\mathrm{ph}}=\mathrm{I}_{\mathrm{sc}}$ While there is no connection to the PV cell (open-circuit), the photon generated current is shunted internally by the intrinsic p-n junction diode [2].

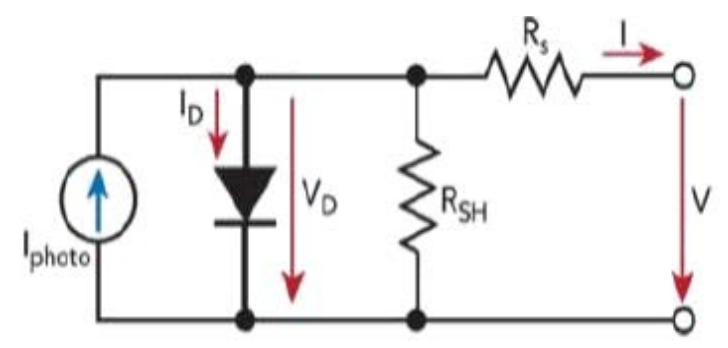

Figure 3. A solar cell equivalent circuit

Using the theory of semiconductors, the I-V characteristic equation of PV cell is given by equation 1.

$I=I_{p h}-I_{0} *\left[e^{(V+I * R S) * \frac{q}{{ }^{*} K * T * N S}-1}\right]-I_{s h}$

Here; $I_{p h}$ is the photocurrent, $\mathrm{I}$ is the total output current, $q$ is the electron charge $(1.602 \times 10-19 \mathrm{C}), K$ is Boltzmann's constant $\left(1.381 \times 10^{-23} \mathrm{~J} / \mathrm{K}\right), A$ is the ideality factor, $N_{p}$ is the number of parallel connected cells, $N_{s}$ is the number of series connected cells, and $T$ represents the absolute temperature in Kelvin.

\subsection{Wind energy modeling}

The wind turbine is a collection of tools used to convert wind energy into electricity. Generally, there are models with 1, 2 or 3 wings. There are wind turbines at different lengths and types, but they are generally classified according to the rotational axes. There are two classes of wind turbines: Horizontal Axis and Vertical Axis. The power generated by the wind turbine is given by equation 2 [3].

$P_{w}=\frac{1}{2} * C_{p} * \rho * \mathrm{~A} * V w^{3}$

Here;

$p$ : the air density $=1.225 \mathrm{~kg} / \mathrm{m}^{3}$,

$C_{p}$ :power coefficient,

$V_{m}:$ the wind speed in $(\mathrm{m} / \mathrm{s})$,

A: the area swept by the rotor in $\left(\mathrm{m}^{2}\right)$,

The amount of torque in $(\mathrm{N}-\mathrm{m})$ is given by equation 3 [3].

$P_{w}=T_{w} W_{w}$

Here;

$T_{w}$ : The amount of torque,

$P_{w}$ : the power from the wind,

$W_{\mathrm{w}}$ : rotor speed in ( $\left.\mathrm{rad} / \mathrm{s}\right)$. 


\subsection{Modeling of STATCOM}

Simply, STATCOM consists of a connection transformer, a converter, and a DC capacitor. $\mathrm{V}_{0}$ is the output voltage of the STATCOM, V is the AC system voltage. It can be used for reactive shunt compensation like TCSVC. It can supply reactive power to the transmission line or can dissipate reactive power from the transmission line to regulate the voltage of the bouquet to which it is connected. The reactive power exchange between the STATCOM and the AC system is controlled by regulating the magnitude of the converter output voltage. If the STATCOM output voltage exceeds the magnitude of the AC system voltage $\left(\mathrm{V}_{\mathrm{O}}>\mathrm{V}\right)$, the current flows from the STATCOM to the AC system via transformer reactance and generates reactive power for the device transmission line. The converter output current is higher than the transmission line voltage. In this case, the device is operating in capacitive mode [7].

In Figure 4, V-I graph of STATCOM is given in continuous operation. It can be seen that in the graphical power system, both inductive and capacitive currents can be provided at certain intervals [7].

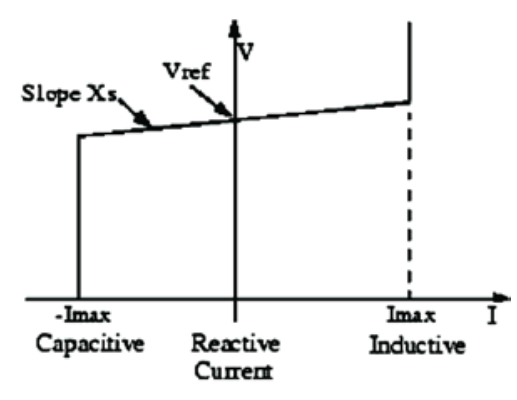

Figure 4. V-I graph of STATCOM

While $I_{d}$ is the direct axis component of the current based on the true power imbalance, $I_{q}$ is the quadrature current. Then, the peak value of the inter-line voltage from the integrated system is calculated by comparing with the reference value, and the difference between these two values gives the desired reactive power in the quadrature current $\mathrm{I}_{\mathrm{q}}[4]$.

Inverse Park’s transformation (dq0-abc transformation) is represented by equation 4 [4].

$$
\begin{aligned}
& \cos (w t) \quad \cos \left(w t-\frac{2 \pi}{3}\right) \quad \cos \left(w t+\frac{2 \pi}{3}\right) I_{a} \\
& I_{d q 0}=T I_{a b c}=\sqrt{2 / 3} \sin (w t) \quad \sin \left(w t-\frac{2 \pi}{3}\right) \quad \sin \left(w t+\frac{2 \pi}{3}\right) I_{b} \\
& \sqrt{2} / 2 \quad \sqrt{2} / 2 \quad \sqrt{2} / 2
\end{aligned}
$$

Simulink model of STATCOM is shown in Fig.5. The STATCOM, which has a power of $+/-3$ MVAR, is connected to the connection point of the system via a reactor and based on the output voltage of STATCOM and the voltage of the transmission line, the STATCOM has absorbed the reactive power generated to the system. 
Nevşehir Bilim ve Teknoloji Dergisi (2018), 7(2) 135-144

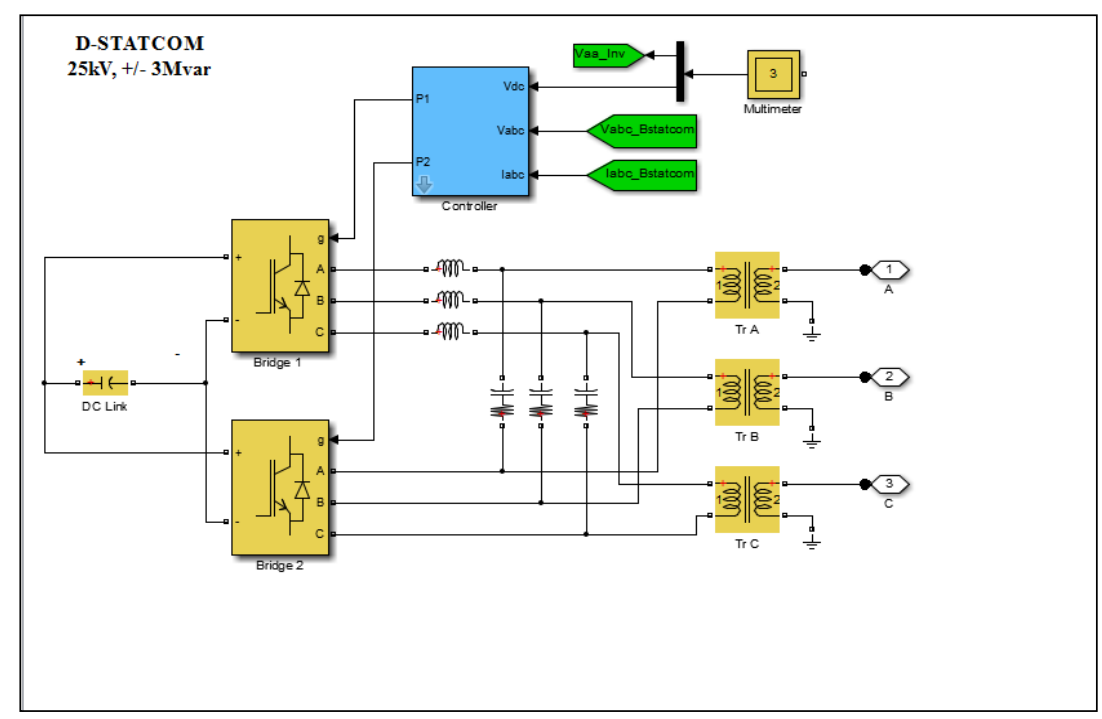

Figure 5. Simulink model of STATCOM

\subsection{Modeling of PV-WIND Hybrid System with STATCOM}

A theoretical study and a Simulink modeling should be done before the actual implementation of these proposed systems. The Simulink model is presented in Figure 6. Firstly, in the system, a solar-wind hybrid model connected to the grid is modeled, and a STATCOM average model of +/-3 MVAR is connected between the load and the grid. Consequently, permanent magnet synchronous generator based wind turbine and with solar panel, a hybrid system with STATCOM is modeled.

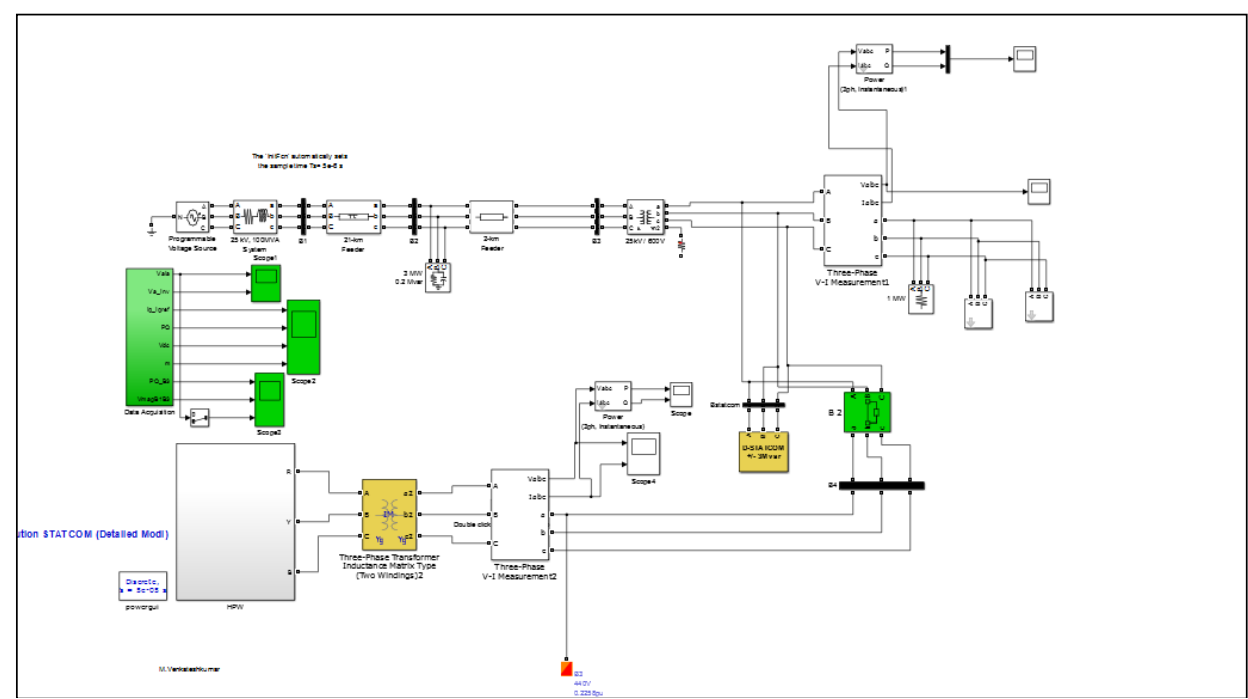

Figure 6. Model of PV-Wind Hybrid System with STATCOM

\section{Results and Discussion}

In the proposed model (seen in Fig.6), first of all, performance of the system without STATCOM under variable load is observed. Then, STATCOM is connected and the changes in the system are explained. Obtained simulation results are presented below. In Fig.7, we observe that the value of peak of PCC (Point Common coupling) voltage equals to $450 \mathrm{~V}$ at $0.35 \mathrm{sec}$ when the D-STATCOM is not operating; when the D-STATCOM is operating, the 
Nevşehir Bilim ve Teknoloji Dergisi (2018), 7(2) 135-144

value of peak of PCC voltage is equal to $500 \mathrm{~V}$ at $0.35 \mathrm{sec}$ (see Fig.7-8). The STATCOM's output voltage and transmission line end voltage are measured in the system and the STATCOM's output voltage is less than the transmission line voltage so the STATCOM has operated in inductive mode and absorbed reactive power from the system. This is shown in Figures 9 and 10.

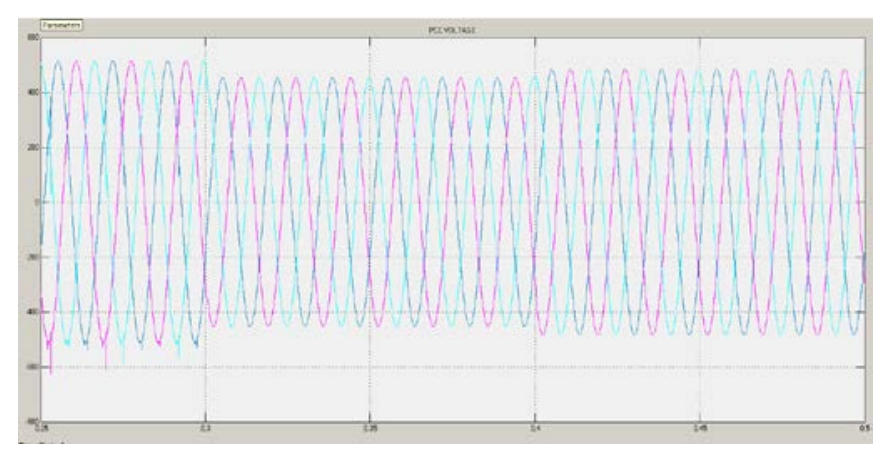

Figure 7. Voltage waveform of HRES without STATCOM under variable load

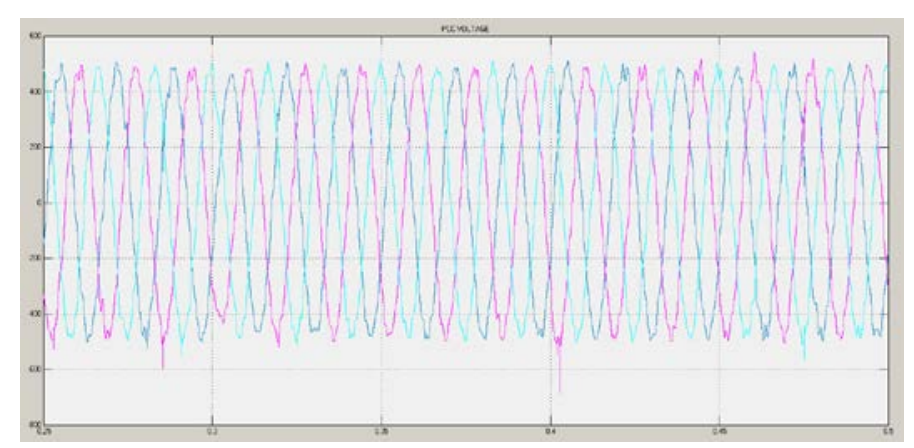

Figure 8. Voltage waveform of HRES with STATCOM under variable load

In Fig.9 the active power (in yellow) and reactive power (in purple) absorbed by the proposed system are observed for the case when STATCOM is not operating. In Fig.10, active power and reactive power exchange as absorbed or generated were observed for the case when STATCOM is operating.

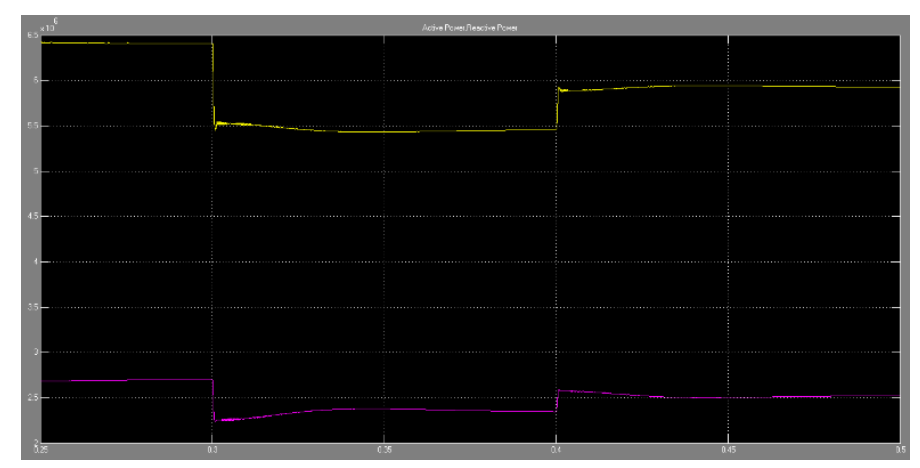

Figure 9. Active and reactive power waveform of HRES without STATCOM under variable load 


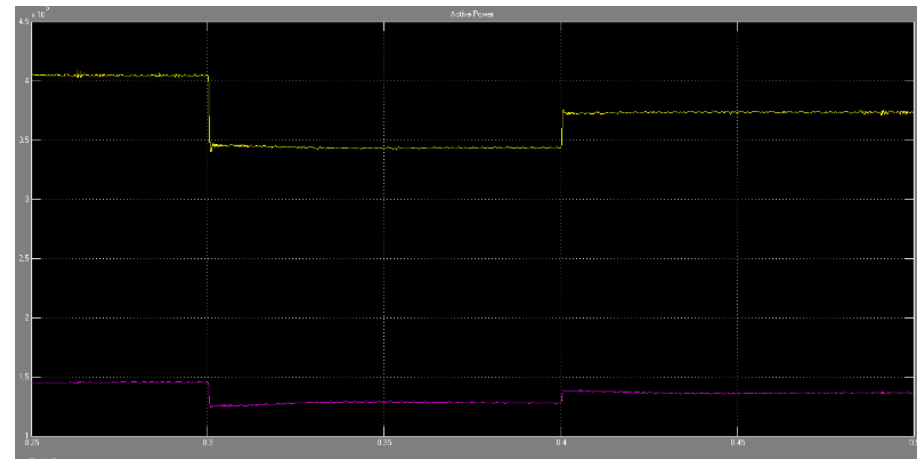

Figure 10. Active and reactive power waveform of HRES with STATCOM under variable load

\section{Conclusion}

As can be seen from the above results, voltage, current and power profiles were obtained in this article and PVWind Hybrid System with STATCOM modeling was done in Matlab Simulink environment. The results suggest that when STATCOM is connected to the system, the voltage increased and the current decreased. When the STATCOM comes into play between load and grid, it can be seen that the voltage profile improves and the reactive power is absorbed or produced at some points in Figure 10. If the converter output is at the forward phase, STATCOM gives active power to the system, while at the reverse phase it draws active power from the system.

Generally, STATCOM supplies reactive power to the system. This is the desired state. The advantage of FACTS controllers such as STATCOM is that it operates faster than conventional mechanical controllers (shunt capacitors, series capacitors, phase shifters, etc.) because they are power electronic based applications. When these controllers are set appropriately, they increase the steady operating limits of the transmission systems. These devices provide control of the power system through appropriate compensation of line parameters such as serial impedance, current, voltage and active and reactive power of the transmission line.

\section{References}

[1] Gupta, A., Saini, R.P., and Sharma, M.P.,’’ Design of an Optimal Hybrid Energy System Model for Remote Rural Area Power Generation’’, ICEE International Conference, Hong Kong, (2007), 1-6.

[2] Kasera, J., Chaplot, A., Maherchandani, J.K., "Modeling and Simulation of Wind-PV Hybrid Power System using MATLAB/Simulink”, 2012 IEEE Students' Conference on Electrical, Electronics and Computer Science, 978-1-4673-1515-9/12/\$31.00 @2012 IEEE.

[3] Kanagasakthivel, B., Devaraj Dr., D., "Simulation and Performance Analysis of Solar PV-Wind Hybrid Energy System using Matlab/Simulink”, 2015 International Conference on Computing and Communications Technologies (ICCCT'15).

[4] Mosobi, W.R., Chichi, T., Gao, S., '’Power Quality Analysis of Hybrid Renewable Energy System’’, Electrical \& Electronic Engineering | Research article, Mosobi et al., Cogent Engineering (2015).

[5] Gümüş, T.H., Yalçın, M.A., 'Facts cihazlarının gerilim kararlılığına etkisinin incelenmesi', Sakarya Üniversitesi, Mühendislik Fakültesi Elektrik-Elektronik Mühendisliği, SAKARYA.

[6] Mithulananthan, N., Sode -Yome, A., and Acharya, N., "Application of FACTS Controllers in Thailand Power Systems”, School of Environment, Resources and Development Asian Institute of Technology, Thailand [2005]. 
Nevşehir Bilim ve Teknoloji Dergisi (2018), 7(2) 135-144

[7] Tosun, S., Öztürk, A., Yalcın, M.A., Döşoğlu, K., Güvenç, U., "Güç Sisteminde SVC ve STATCOM Denetleyici Etkilerinin İncelenmesi”, 6th International Advanced Technologies Symposium (IATS’11), 16-18 May 2011, Elazı̆ğ, Turkey.

[8] N.G. Hingorani and L. Gyugyi. "Understanding FACTS:concepts and technology of flexible ac transmission systems”, IEEEPress. New York, (1999). 


\section{Genişletilmiş Özet}

\section{Giriş}

Güç sistemlerinde güneş ve rüzgar santrallerinin güç kapasitelerinin hızla artması, büyük güçlü santrallerinin güç sistemine etkilerinin incelenmesini gerektirmektedir. Enerji iletim sistemlerinin kontrolünde en önemli sorunlardan bir tanesi de reaktif güç kompanzasyonudur. Reaktif güç, iletim sistemlerinde kayıpların artmasına, iletim hattından taşınan güç kapasitesinin azaltılmasına ve hat sonundaki gerilimin genliğinde değişmelere neden olmaktadır. Bundan dolayı iletilebilir gücü artırmak, kayıpları azaltmak ve gerilimin genliğinin kararlılığını sağlamak için reaktif güç kompanzasyonu yapmak gerekir. Buna bağlı olarak enerji iletim ve dağıtım sistemleri için hızlı kompanzasyon ihtiyacı giderek önem kazanmaktadır. Günümüzde, esnek alternatif akım iletim sistemleri (FACTS) ile karmaşık ve büyüyen sistemlerin güç sorunları daha hızlı ve etkili bir şekilde cevap vermektedir. Buna ek olarak, FACTS cihazları uygun bir şekilde kullanıldığında, güç sistemlerinin kararlılık sınırlarını artırmakta ve yük artışı ya da yenilenebilir enerji kaynaklarının sisteme eklenmesi ile oluşan gerilim dalgalanmasını minimize ederek, reaktif güç kompanzasyonu sağlamakta ve mevcut kaynakların mümkün olan en iyi şekilde kullanılmasını sağlamaktadır. En tanınmış FACTS cihazları arasında Static VAR Kompensator (SVC), Static Senkron Kompensator (STATCOM) bulunmaktadır. Bu çalışma MATLAB/Simulink'te STATCOM ile Rüzgar-PV Hibrit üretim sisteminin modellenmesi ve analizi üzerine odaklanmaktadır. STATCOM'un hibrit yenilenebilir enerji sistemi (HRES) üzerindeki etkisi araştırılmıştır. STATCOM, iletim sistemlerinde reaktif güç kompanzasyonu sağladığı için, sistem tarafindan arzu edilen reaktif güç absorbe edilmekte veya üretilmektedir.

\section{Yöntem}

Güneş 1şınımı ve rüzgârın doğal kesikli özelliklerinden dolayı şebekeden bağımsız rüzgâr/FV gibi yenilenebilir enerji sistemleri, her an değişen yük talebini karşılamada tamamen güvenli olmadığından, güç kararsızlıkları yaşanmaktadır ve reaktif güç kompanzasyonu yapılarak hibrit bir sistem oluşturmak mantıklı bir çözüm haline gelmiştir. Gerilim kararsızlığının temel sebebi yükteki artıştır. Güç sistemlerindeki kararsızlık, FACTS cihazlarının kullanımıyla giderilir veya en azından minimize edilir. Bu çalışmada sistemin ve yenilenebilir enerji kaynaklarından dolayı oluşan gerilim dalgalanması azaltmak ve reaktif güç kompanzasyonu için sisteme şönt olarak bağlanan bir FACTS cihazı olan STATCOM eklenerek sistemin kararlı çalışma limitinin artırılması planlanmaktadır. STATCOM çıkışında şebeke frekansında, kontrol edilebilir genlikte ve faz açısında, dengeli üç faz gerilimleri elde edilir. Bu düzenlemede AC sistem ile aygıt arasındaki sürekli durum güç alışverişi genel olarak reaktiftir. STATCOM ve AC sistem arasındaki reaktif güç alış verişi konverter çıkış geriliminin büyüklüğünü düzenleyerek kontrol edilir. Eğer STATCOM çıkış geriliminin büyüklüğü $\mathrm{AC}$ sistem geriliminin büyüklüğünü geçerse ( $\mathrm{VO}>\mathrm{V}$ ) I akımı transformatör reaktansı yolu ile STATCOM'dan AC sisteme akar ve cihaz iletim hattı için reaktif güç üretir. Konverter çıkış akımı iletim hattı geriliminden ileridedir. Bu durumda cihaz kapasitif modda çalışmış olur. STATCOM sistemin kendinden kaynaklı ya da hibrit sistemlerden kaynaklı yük artışına bağlı oluşan gerilim dalgalanmalarını azaltmada etkilidir. Dalgalanmanın oluştuğu noktalarda reaktif güç üretme veya tüketme ile reaktif güç kompanzasyonu ile bara sonundaki gerilim dalgalanmasını kaldırır ve enerjinin en küçük alıcıya sorunsuz bir şekilde iletilmesini sağlar. Hibrit sistemlerin modellemesi ve STTACOM kontrol devresi ve modellemesi üzerine çalışmalar yapılmıştır ve sonuçlar Matlab/Simulink ortamında gösterilmiştir.

\section{Sonuçlar ve Tartı̧sma}

Matlab Simulink ortamında STATCOM ve PV-Rüzgar Hibrit Sistemi üzerine çalışma yapılmış ve sonuçlar STATCOM sisteme bağlandığında voltajın arttığını ve akımın düştüğünü göstermektedir. STATCOM, yük ve şebeke arasında devreye girdiğinde, voltaj profilinin iyileştirildiği ve reaktif gücün, Şekil 10'daki bazı noktalarda tüketildiği veya üretildiği görülmektedir. Dönüştürücü çıkışı ileri fazdaysa, STATCOM aktif güç verir. Sistem ters fazdayken sistemden aktif güç çeker. Genel olarak, STATCOM sisteme reaktif güç sağlar. Bu istenen durumdur. STATCOM gibi FACTS kontrol cihazlarının avantajı, geleneksel mekanik kontrol cihazlarından (şönt kapasitörler, seri kapasitörler, faz kaydırıcılar vb.) Daha hızlı çalışmasıdır çünkü güç elektroniği uygulamalarıdır. Bu çalışmada 5 kW’’ık bir sürekli mıknatıslı senkron jeneratör tabanlı bir rüzgar üretim sisteminin şebekeye etkisi incelenmiş ve daha sonrasında $1 \mathrm{~kW}$ 'lık güneş üretim sistemin şebekeye etkisi incelenmiş, tüm sistem hibrit bir yapı haline getirilerek güneş ve rüzgar gibi yenilenebilir enerji kaynaklarının voltaj profilinde dalgalanmalara sebep olduğu ve reaktif güç kompanzasyonunun STATCOM ile sağlanabileceği üzerine çalışılmıştır. Güneş-Rüzgar bir hibrit sistem tasarlanarak çıkıştaki güç profilleri incelenmiş ve STATCOM ilave edilerek kapasitif ve reaktif çalışma durumlarına göre sistemdeki güç profilleri incelenmiştir. Bu kontrolörler uygun şekilde ayarlandığında, iletim sistemlerinin sabit çalışma sınırlarını arttırırlar. 